\title{
E-Learning During Covid-19: Towards AlMaarif University College
}

\author{
Abdulkareem Dawah Abbas*, Ahmed Shamil Mustafa, Yassin Salih Fayyad, Mustafa Maad Hamdi \\ Department of Computer Engineering Techniques, Al-Maarif University College, Iraq \\ *ahmedshamil90@gmail.com
}

\begin{abstract}
:
E-learning is one way to make more learners more accessible and flexible and to close the divide between different fields or cultures or time management to the satisfaction of students. The purpose of this paper is to review the current literature on the benefits of online learning from the satisfaction of students in applied technology and the form of blended learning used in the learning process in order to build qualifications and enhance learning outcomes. The methodology focuses on explaining the different ways of e-learning methods and how to communicate through common communication models. The results of this paper demonstrate the effects of the 2019-2020 empiric study of e-learning at the University of Al-Maarif. The study further draws on its clear proof of the satisfaction of students with e-learning models.
\end{abstract}

Keywords: E-Learning; Online Teaching; Higher Education.

Crossref doi https://doi.org/10.51345/.v31i1.349.g163 


\section{INTRODUCTION}

In the last decade e-learning has become part of education and universities have adopted interactive educational resources as well as advanced web platforms to deliver quality education from a conventional campus (Andone et al., 2017). The methods used by universities to provide online resources by formal education are generally referred to as LMS which LCMS, or are available in different formats, both commercial as an open-source, or simply referred to as learning platforms (Andone et al., 2017; Miller, 2018; Rennie \& Morrison, 2013).

E-learning classes are a new complement to formal education and often are also an option. It makes for high-level schooling, which is accessible everywhere and at all times (Mehdipour \& Zerehkafi, 2013). The use of an original specially designed instructional text, such as syllabuses, presentations, immersive lessons, instructional videos, and many other multimedia materials, allows distance learning successful and often correlates with students ' expectations. The idea that a modern method of education makes it possible to validate information almost instantly is important (Ghirardini, 2011).

According to their functionality, this approach enables operations to be carried out in two directions. Distance learning is a curriculum that removes an instructor from the human environment. Yes, the basis of the information to research and analyze is a machine linked to the Internet. E-learning is mainly used as a method for promoting instruction. In conjunction with interactive communication systems, teachers and students conduct courses in the conventional manner (Plebańska \& Kula, 2011).

While the e-learning concept and methods have been available for over ten years, the field of educational science has neglected to pay adequate attention to researching student engagement under the influence of e-learning. E-learning has been a significant method as technology over years has advanced and improved. Interestingly, more attempts have been made to improve technologies than to strive to consider the needs and preferences of particular learners and the teaching environment. Stuff like the Internet and professional schooling have changed rapidly throughout the 21st Century (Abou El-Seoud et al., 2014).

Given the tremendous increase and perceived advantages of e-learning, the effectiveness of such instruments is not exploited entirely if consumers are unable to embrace and use the system. Therefore, it depends upon students being prepared to embrace and take advantage of the technologies if elearning resources are successful. It is therefore important for practitioners and policymakers to consider the factors influencing user acceptability of web-based applications to improve the learning experience of students (Tarhini et al., 2014). In the spread of new media in higher education, the researchers (Heinz \& Koehler) made a substantial contribution. The researchers found that the comprehensive study of seven years of frequency spread reflects the intensity of empirical debate about e-learning patterns and assumptions can be drawn about the didactic or technological potential of innovation. Specifically, the growth capacity of learning management, mobile learning, and e-portfolio is essential for eLearning in German university education. They also include social media and large open-line courses. However, recent findings have shown that adoption of e-learning is not merely a technical approach but is, in addition to behavioral and cultural influences, a continuum of multiple factors such as social factors and human factors, interpersonal and organizational (Kattoua et al., 2016).

In the learning process, integrating technology would not inherently ensure inspired students. In reality, online education has contributed to a less intimate partnership with the student instructor. The 
classroom must be transformed into an immersive space by instructors. What exactly does a teacher need in an online world to inspire students? (Abou El-Seoud et al., 2014; Koehler et al., 2007).

Teachers need to consider the motives of their pupils. While students take online classes in order to complete them successfully, there are a variety of reasons for failure. The success or lack of online training can be attributed to the enthusiasm of the pupil (Nehme, 2010).

\section{The Research Questions}

This research paper will answer the following questions.

- To what extent of Al-Maarif University students accept e-learning?

- What is the best way for a student to learn through the internet?

- $\quad$ Did e-learning increase the closeness between the student and the teacher?

- Does E-learning develop the creative thought of the male and female students?

- $\quad$ Is the age of students at Al-Maarif University College affect learning?

\section{The Objective and Hypothesis}

The research's key goal was to assess and appreciate what strategies are used by students, such as what they have favored video recording, live meetings, PDF notes, etc. Besides, the analysis aims to improve the enthusiasm of undergraduate students at Al-Maarif University for learning for the benefit of collaborative features of e-learning makes this study relevant is that it provides knowledge of the value of utilizing immersive e-learning apps as a valuable tool in teaching students through academic staff at Al-Maarif University College.

Three theories in science have been tested in this analysis to decide what theories would be approved and dismissed.

- $\quad$ Participants demonstrate a disparity in e-learning behaviors depending on the faculties teaching.

- $\quad$ The test performance would have an impact regardless of online choice.

- In comparison to the conventional learning process, students would tend to e-learning.

\section{RESEARCH METHOD AND DATA COLLECTION:}

The experiments were carried out at the Al-Maarif University College, Ramadi, Iraq. The research sample consists of some students at Al-Maarif University College who have completed their academic year 2019-2020 by e-learning studies. Google Forms were used to create a sample questionnaire and distribute it electronically to students by sharing a link on the university's website and an official Facebook page.

The research focused on different age groups in order to find out the effect of changing the study way system on them. It is known that the Al-Maarif University contains morning studies for age groups ranging from (18 to 22) years and evening studies, including age groups of 30 years and older. Research has also focused on academics who work at the university, and questions have been directed to them to find out how they are affected by the change in the study system, especially for academics with humanitarian and elderly specialties. Table 1 shows the number of responses received by age group, gender, and others. While the total number of sample studies was 769. 
Table 1 Descriptive Statistics for Demographic Data of the Sample Study (N=769)

\begin{tabular}{llll}
\hline Data variable & & Count & Percent $(\%)$ \\
\hline \multirow{2}{*}{ Age } & $18-25$ & 435 & 56.7 \\
& $26-35$ & 202 & 26.3 \\
\multirow{2}{*}{ Gender } & $36-50$ & 118 & 15.4 \\
& $50-70$ & 12 & 1.6 \\
Professional & Male & 594 & 77.2 \\
Status & Female & 175 & 22.8 \\
\hline
\end{tabular}

\section{RESULT:}

In table 2, it shows the results which answer to know to what extent of Al-Maarif University students accept e-learning.

Table 2 Descriptive statistics for the extent the students accept e-learning.

\begin{tabular}{|c|c|c|c|c|c|c|}
\hline No & Questions & & Agree & Disagree & Mean & $\begin{array}{l}\text { Std. } \\
\text { Deviation }\end{array}$ \\
\hline \multirow[t]{2}{*}{1} & $\begin{array}{l}\text { Do you want to } \\
\text { have tests on the } \\
\text { electronic }\end{array}$ & $\mathrm{N}$ & 379 & 390 & \multirow[b]{2}{*}{1.50} & \multirow[b]{2}{*}{0.50} \\
\hline & $\begin{array}{l}\text { platforms, no } \\
\text { matter what the } \\
\text { type of application? }\end{array}$ & $\%$ & $49.3 \%$ & $50.7 \%$ & & \\
\hline \multirow[t]{2}{*}{2} & $\begin{array}{l}\text { When returning to } \\
\text { school seats, God } \\
\text { willing, would you }\end{array}$ & $\mathrm{N}$ & 291 & 478 & \multirow[t]{2}{*}{1.62} & \multirow[t]{2}{*}{0.48} \\
\hline & $\begin{array}{l}\text { like to continue this } \\
\text { type of learning? }\end{array}$ & $\%$ & $37.8 \%$ & $62.2 \%$ & & \\
\hline \multicolumn{3}{|c|}{ Mean } & \multicolumn{3}{|c|}{1.56} & \\
\hline \multicolumn{3}{|c|}{ Std. Deviation } & \multicolumn{3}{|c|}{0.40} & \\
\hline
\end{tabular}

Table 3 Descriptive statistics for how would you like the lecture to be?

\begin{tabular}{llcccc}
\hline No & Questions & & YouTube & PDF & Broadcast Live \\
\hline 1 & $\begin{array}{l}\text { How would you like } \\
\text { the lecture to be? }\end{array}$ & $\mathrm{N}$ & 391 & 123 & 37 \\
& $\%$ & $71.0 \%$ & $22.3 \%$ & $6.7 \%$ \\
\hline
\end{tabular}


Table 4 Summary statistic answers to the research questions

\begin{tabular}{llll}
\hline Questions & Mean & Std. Deviation & Sample (N) \\
\hline $\begin{array}{l}\text { To what extent of Al-Maarif University } \\
\text { students accept e-learning? }\end{array}$ & 1.56 & 0.40 & 769 \\
$\begin{array}{l}\text { What is the best way for the student to } \\
\text { learn through the Internet? }\end{array}$ & 0.178 & 551 \\
$\begin{array}{l}\text { Did e-learning increase the closeness } \\
\text { between the student and the teacher? }\end{array}$ & 2.0884 & 0.80363 & 769 \\
$\begin{array}{l}\text { Does E-learning develop the creative } \\
\text { thought of the male and female students? }\end{array}$ & 0.8778 & 0.74522 & 769 \\
\hline
\end{tabular}

\section{CONCLUSION:}

This paper provides an opinion poll on the impact of e-learning on the usage of a group of academics and students of Al-Maarif University College. Their significance in the field of education. The research will extend the technologies and provide educational planners with resources to improve strengths and shortcomings in the operations and distribution processes. Successful e-learning architecture includes an input that improves the experience and encourages students to increase their skills and expertise. The universities 'willingness to implement several approaches for studying and teaching using an immersive communication approach is a reaction to today's generation of students' demands. Young people addicted to the everyday use of electronic media enjoy very much the access to digital technology. Young people consider e-learning as an enticing and modern learning process. Learning on the Internet helps it to conquer educational obstacles with its conclusions.

\section{REFERENCES:}

Abou El-Seoud, M., Taj-Eddin, I., Seddiek, N., El-Khouly, M., \& Nosseir, A. (2014). E-learning and students' motivation: A research study on the effect of e-learning on higher education. International journal of emerging technologies in learning (iJET), 9(4), 20-26.

Andone, D., Ternauciuc, A., \& Vasiu, R. (2017). Using Open Education Tools for a Higher Education Virtual Campus. 2017 IEEE 17th International Conference on Advanced Learning Technologies (ICALT).

Ghirardini, B. (2011). E-learning methodologies: A guide for designing and developing e-learning courses. Food and Agriculture Organization of the United Nations.

Heinz, H. F. L. H. M., \& Koehler, K. M. T. How to identify e-learning trends in academic teaching: Methodological approaches and the analysis of scientific discourses. education, 11(4), 287301.

Kattoua, T., Al-Lozi, M., \& Alrowwad, A. a. (2016). A review of literature on E-learning systems in higher education. International Journal of Business Management \& Economic Research, 7(5), 754-762.

Koehler, M. J., Mishra, P., \& Yahya, K. (2007). Tracing the development of teacher knowledge in a design seminar: Integrating content, pedagogy and technology. Computers \& Education, 49(3), 740-762.

Mehdipour, Y., \& Zerehkafi, H. (2013). Mobile learning for education: Benefits and challenges. International Journal of Computational Engineering Research, 3(6), 93-101. 
Miller, B. (2018). Smartphones for online study: effects on learning and engagement University of Liverpool.

Nehme, M. (2010). E-learning and students' motivation. Legal Educ. Rev., 20, 223.

Plebańska, M., \& Kula, I. (2011). E-learning: treści, narzędzia, praktyka. ALMAMER Szkoła Wyższa.

Rennie, F., \& Morrison, T. (2013). E-learning and social networking handbook: Resources for higher education. Routledge.

Tarhini, A., Hone, K., \& Liu, X. (2014). The effects of individual differences on e-learning users' behaviour in developing countries: A structural equation model. Computers in Human Behavior, 41, 153-163. 